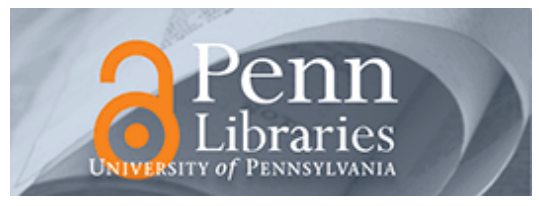

University of Pennsylvania

ScholarlyCommons

Management Papers

Wharton Faculty Research

$1-2008$

\title{
Knowledge Flows Within Multinational Corporations: Explaining Subsidiary Isolation and Its Performance Implications
}

L. Felipe Monteiro

University of Pennsylvania

Niklas Arvidsson

Julian Birkinshaw

Follow this and additional works at: https://repository.upenn.edu/mgmt_papers

Part of the Business Administration, Management, and Operations Commons, and the International Business Commons

\section{Recommended Citation}

Monteiro, L., Arvidsson, N., \& Birkinshaw, J. (2008). Knowledge Flows Within Multinational Corporations: Explaining Subsidiary Isolation and Its Performance Implications. Organization Science, 19 (1), 90-107. http://dx.doi.org/10.1287/orsc.1070.0264

This paper is posted at ScholarlyCommons. https://repository.upenn.edu/mgmt_papers/109

For more information, please contact repository@pobox.upenn.edu. 


\title{
Knowledge Flows Within Multinational Corporations: Explaining Subsidiary Isolation and Its Performance Implications
}

\author{
Abstract \\ Applying a new theoretical and empirical approach to intrafirm knowledge transfers, this paper provides \\ some initial insight to the little-researched phenomenon of why some subsidiaries are isolated from \\ knowledge-transfer activities within the multinational corporation (MNC). Knowledge transfer is framed \\ as a problemistic search process initiated by the recipient unit. We show that knowledge flows from units \\ that are perceived to be highly capable to units that perceive themselves to be highly capable. Knowledge \\ flows are also associated with existing levels of communication and reciprocity. Taken together, these \\ findings suggest that knowledge transfers in MNCs typically occur between highly capable members of \\ an "in crowd," and the isolated minority rarely, if ever, engages in knowledge-sharing activities. Finally, we \\ show that the isolated minority underperforms other subsidiaries, suggesting the possibility of a "liability \\ of internal isolation."

\section{Keywords} \\ knowledge flows, multinational management, subsidiary performance, subsidiary isolation, perception \\ gaps, behavioral theory of the firm

\section{Disciplines} \\ Business Administration, Management, and Operations | International Business
}




\title{
KNOWLEDGE FLOWS WITHIN MULTINATIONAL CORPORATIONS: EXPLAINING SUBSIDIARY ISOLATION AND ITS PERFORMANCE IMPLICATIONS
}

$=$

$=$

L. FELIPE MONTEIRO

London Business School

Sussex Place, Regent’s Park

London NW1 4SA, United Kingdom

Tel: + 44 (0)20 72625050

e-mail: fmonteiro@london.edu

\section{NIKLAS ARVIDSSON}

Service Management Group SMG AB

P.O. Box 5661

SE-114 86 Stockholm

Sweden

Tel: ++ 46 0708-698914

e-mail: arvidsson_niklas@spray.se

\author{
JULIAN BIRKINSHAW \\ London Business School \\ Sussex Place, Regent’s Park \\ London NW1 4SA, United Kingdom \\ Tel: + 44 (0)20 72625050 \\ email: jbirkinshaw@london.edu
}

An earlier version of this paper was published at the Best Papers Proceedings of the Academy of Management Conference, New Orleans. We thank Harry Barkema, Tina Chini, P.Cristopher Earley, Cristina Gibson, Bjorn Lovas, Phanish Puranam, Catalina Stefanescu and Freek Vermeulen for their helpful advice, comments and suggestions. 


\section{KNOWLEDGE FLOWS WITHIN MULTINATIONAL CORPORATIONS: EXPLAINING SUBSIDIARY ISOLATION AND ITS PERFORMANCE IMPLICATIONS}

$=$

\section{ABSTRACT}

Applying a new theoretical and empirical approach to intra-firm knowledge transfers, this paper provides some initial insight to the little-researched phenomenon of why some subsidiaries are isolated from knowledge transfer activities within the MNC. Knowledge transfer is framed as a problemistic search process initiated by the recipient unit. We show that knowledge flows from units that are perceived to be highly capable to units that perceive themselves to be highly capable. Knowledge flows are also associated with existing levels of communication and reciprocity. Taken together, these findings suggest that knowledge transfers in MNCs typically occur between highly capable members of an in-crowd, while the isolated minority rarely, if ever, engage in knowledge sharing activities. Finally, we show that the isolated minority underperforms other subsidiaries, suggesting the possibility of a "liability of internal isolation". 
Over the last several years there has been widespread interest among scholars in the importance of knowledge management in organisations and, particularly, in multinational corporations (e.g. Eisenhardt \& Santos, 2002; Ghoshal \& Bartlett, 1988; Gupta \& Govindarajan, 2000; Schulz, 2001, 2003; Szulanksi, 1996; Zander \& Kogut, 1995). The idea that multinational corporations (MNCs) create value from the internalization of their accumulated knowledge and from their knowledge "assets” (e.g. patents, trade secrets, and organizational routines) can be traced back to the pioneering work of Hymer (1960), Caves (1971) and Buckley \& Casson (1976), among others. Today there is a broad consensus that a MNC is "an international network that creates, accesses, integrates and applies knowledge in multiple locations” (Almeida, Song \& Grant, 2002:148). In order to respond effectively to its environmental heterogeneity, the MNC must differentiate the activities of its subsidiaries but it must also integrate them (Ghoshal \& Nohria, 1989).As Schulz (2003) puts it, the integration of the knowledge of the MNC on a worldwide basis, although difficult, is what enables MNCs to reap the “incremental value of being multinational” (Kogut, 1989: 383).

The reality, however, is that knowledge integration within the MNC is far from perfect. There is ample evidence in the literature that knowledge is sticky and that leading-edge management practices do not flow rapidly and uneventfully from country to country (e.g. Chew, Bresnahan and Clark, 1990; Leibenstein, 1966; Szulanski, 1995, 1996; Teece, 1981). Prior research has examined the difficulties of transferring tacit and complex knowledge within the organization (e.g. Szulanksi, 1996; Zander \& Kogut, 1995), the importance of motivation and absorptive capacity for transferring knowledge (e.g. Gupta \& Govindarajan, 2000) and the relevance of central network positions in intraorganizational knowledge transfers (e.g. Tsai, 2001).

An equally important but underexplored phenomenon is the tendency for some subsidiaries to be isolated from the knowledge transfer activities within the MNC. Previous research (e.g. Gupta \& Govindarajan, 2000; Hansen \& Lovas, 2004) has implicitly indicated the existence of subsidiaries that are isolated from intra-firm inflows and outflows of knowledge. And our data, as described later, reveals the magnitude of this phenomenon: out of our sample of 171 subsidiary units, 22\% experienced inflows of new products or practices from the MNC's headquarters less than once per year, $42 \%$ participated in outflows of new products or practices less than once per year, and $13 \%$ 
experienced neither inflows nor outflows more than once per year. These isolated subsidiaries may well be underperforming in their local markets if they do not have access to the broader knowledge base of the MNC, and their existence may also be symptomatic of a more fundamental problem of knowledge sharing in the corporation.

However, there is practically no attempt to explain theoretically and empirically the reasons why some subsidiaries are isolated from the knowledge transfer activities within the MNC nor the impact of internal isolation on subsidiary performance. Instead, most of the existing literature tend to focus on identifying the barriers and facilitators of knowledge transfers from the perspective of those subsidiaries that are already involved in knowledge transfer activities - colloquially known as the "incrowd"-and disregards the group of subsidiaries that is simply isolated from any knowledge transfer activity within the MNC. For instance, the very way Szulanski (1996) designed his research ensured that it took into account only those units that were already involved with a best-practice transfer. And even those studies (Gupta \& Govindarajan, 1991, 1994) that explicitly indicate that some subsidiaries (e.g. "local innovators") may not participate in the knowledge sharing activities within a MNC fail to investigate what are the performance consequences of subsidiary isolation for the "isolated" subsidiaries (i.e. those that experience few if any intrafirm knowledge outflows or inflows).

We believe that it is important to advance the literature on intrafirm knowledge transfers by investigating the isolated subsidiary phenomenon and its performance consequences. Two questions guide our research. First, what explains the pattern of knowledge flows that give rise to subsidiary isolation? Second, what is the impact of subsidiary isolation on subsidiary performance?

Unlike Gupta and Govindarajan (2000) who used communication theory (2000:475), we address our first question by developing a demand-driven model of knowledge flow that builds on the behavioural theory of the firm (Cyert and March, 1963). And unlike Gupta and Govindarajan (2000) who focused on the transmission of knowledge between sender and recipient, our relative emphasis is on the initiation of that process (Szulanski, 1996; 2000). We focus on the recipients of knowledge flows as they engage in a process of problemistic search within the context of a MNC in which there is very limited awareness of where its useful knowledge resides. This framing suggests that the subjective evaluation of a subsidiary's capabilities by itself and by others drives the knowledge flow 
process. As we describe in detail below, knowledge outflows are predicted by other units evaluating the focal subsidiary highly, whereas inflows are predicted by the focal subsidiary evaluating itself highly. And those units that are evaluated poorly by both themselves and by others are likely to become isolated. We also suggest that the level of communication and the existence of reciprocity between units will further strengthen these patterns of knowledge flow, thereby exacerbating the phenomenon of subsidiary isolation. This pattern may result in some subsidiaries finding themselves in self-reinforcing spirals of knowledge sharing with others, while the self-reinforcing cycle is a downward spiral for the isolated subsidiaries that neither send nor receive knowledge flows.

Equally important in this paper is the examination of the performance of isolated subsidiaries vis-à-vis that of subsidiaries which participate in the knowledge transfer activities within the MNC. We will argue that subsidiaries that are alienated from the knowledge transfer activities within the firm not only fail to benefit from the specific knowledge of other units within the MNC (e.g. new products developed by another subsidiary), they also end up not participating in an information network that is a vehicle for the rapid communication of news about opportunities and obstacles. We conjecture that similar to the idea of liability of (external) unconnectedness (Powell, Koput and Smith-Doerr, 1996) there is a liability of internal isolation and we hypothesize that, all other things equal, the isolated subsidiaries have a lower performance than those subsidiaries that regularly receive and send knowledge within the MNC.

In the body of the paper, we conduct an empirical test of these arguments using nodal data that focuses on the perceived capabilities, knowledge flows, and performance of subsidiary units. We should also note at this stage that we focus on one specific type of knowledge: marketing knowledge—-know-how about new products and new services and marketing best practices. Knowledge inflows are therefore the aggregate volume of know-how about new products and new services and marketing best practices received either from other subsidiaries (horizontal inflows) or from the MNC headquarters (vertical inflows) by the focal subsidiary; and knowledge outflows are the aggregate volume of know-how about new products and new services and marketing best practices transmitted from the focal subsidiary to other subsidiaries (horizontal outflows) or to the HQ (vertical outflows). 
Our data set consists of questionnaire responses from the managers of 171 subsidiaries belonging to six large Swedish multinationals (Sandvik Steel, Coromant, Ericsson, Volvo, Pharmacia and Alfa Laval Agri), plus evaluations of those same subsidiaries by their corporate HQ and their peers. We receive broad support for the arguments. In the final section of the paper, we discuss the implications of our findings for both theory and practice.

\section{THEORETICAL DEVELOPMENT AND HYPOTHESES}

What is the nature of knowledge flows in a MNC where knowledge is dispersed, sticky, and imperfectly evaluated? In this section we develop a set of theoretical arguments based on the behavioural theory of the firm (Cyert and March, 1963), which leads to the development of specific hypotheses regarding the conditions under which we would expect to see knowledge flows into and out of the focal subsidiary.

\section{Problemistic Search and Perception Gaps}

The behavioural theory of the firm is rooted in the pioneering work of Herbert Simon and James March (March and Simon, 1958; Simon, 1947) and was formally introduced in Cyert and March's (1963) book of the same name. The principles of this theory are now applied broadly in the organisational literature in such sub-fields as organizational learning, decision theory, and the internationalization of the firm (Johanson and Vahlne, 1977). In this paper we build on assumptions that managers are boundedly rational (i.e. they have significant cognitive limitations) and that they satisfice (i.e. they seek out an acceptable solution to a problem, rather than an optimal one). We then focus on the process of problemistic search, that is "search that is stimulated by a problem and is directed toward finding a solution to that problem” (Cyert and March, 1963: 121). Problemistic search is assumed to be (1) motivated by a particular problem such as a failure to satisfy one of its goals, it is (2) simple-minded, meaning that it proceeds on the basis of a simple model of causality unless driven to a more complex one, and it is (3) biased, meaning that the search process is steered by the prior experiences and goals of the managers driving it (Cyert and March, 1963: 121).

Consider these arguments now in the context of the MNC. We suggest that knowledge transfer between units can be framed as a process of problemistic search on the part of the recipient. Knowledge transfers, by definition, involve both a source and a recipient, but by framing the 
discussion in this way we are suggesting that a primary driver of the process is the perceptions of the recipient. Several academic studies, for example, have shown that attributes of the recipient are significantly associated with the level of knowledge flows (Gupta and Govindarajan, 2000; Szulanski, 1995), and others have explicitly focused on the recipients’ search process (Hansen and Haas, 2001). The broader literature on knowledge management has emphasized the value of a demand-driven approach to knowledge transfer (Stewart, 1998; Davenport and Prusak, 1998), and problem-driven search is also emphasized in the innovation literature (Adner and Levinthal, 2001; Dosi, 1988; Schmookler, 1965). By framing our research in this way, we are not in any way denying the importance of a motivated knowledge source or a well-managed process for achieving effective knowledge transfer (Szulanski, 1995). Rather, we are simply suggesting that by better understanding the process of search that the recipient pursues, we can generate useful insights into the patterns of knowledge flow we observe in reality.

A knowledge flow in the MNC is therefore viewed as being motivated in large part by a specific problem facing a specific unit, such as a failure to meet profitability or productivity goals ${ }^{1}$. When faced with such a problem, the managers of the unit begin to search for a solution, and as predicted by the Behavioural Theory of the Firm, their search proceeds in a "simple minded" and "biased” way (Cyert and March, 1963: 121). That is, they search on the basis of simple heuristics and typically through existing and easily-available solutions, rather than through an exhaustive evaluation of all possible solutions. Once an acceptable solution has been found, perhaps through a knowledge transfer with another unit of the MNC, or perhaps through an external relationship, the search process stops.

We argue that in order to understand subsidiary isolation we need to place increased focus on the initiation stage of a knowledge transfer-i.e. those events that lead to the decision to transfer (Szulanski, 1996:28)—and examine what are the heuristics that managers are likely to use to evaluate whether to engage in a process of internal knowledge transfer. We expect that an important determinant will be the perceptions (on the part of the potential recipient) of the whereabouts of

\footnotetext{
${ }^{1}$ To be clear, this logic does not apply to those cases of HQ-mandated initiatives where the subsidiary has no option whether it conforms or not. However, our sense from the research interviews we conducted for this study is that the sales and
} 
valuable capabilities within the MNC. These perceptions may or may not be based on solid foundations, but from a problemistic search perspective they are likely to provide sufficient information for the managers in question to act.

However, as noted in the introduction, there is now considerable evidence that the evaluation of capabilities in the MNC is highly imperfect. Knowledge assets, by their nature, are hard to evaluate, and rarely given explicit attention (Galunic \& Rodan, 1998; Szulanski, 1996). When combined with the sticky and dispersed nature of knowledge in the MNC, the result is often considerable disagreement between subsidiary units, and between the subsidiary and the corporate HQ, as to where valuable capabilities reside. For example, in the most comprehensive study of this subject to date, Denrell, Arvidsson and Zander (2004) found that the median correlation between the subsidiary's selfevaluation of its capabilities, and the corresponding evaluation by HQ, was just 0.28 . Similarly weak levels of agreement have been found in other MNC studies (Birkinshaw, Holm, Thilennius and Arvidsson, 2001) as well as in the analogous literature on supervisor/subordinate performance evaluations (Bommer et al, 1995; Harris \& Schaubroek, 1988).

We can expect, in other words, to see large differences in the evaluation of a focal subsidiary's capabilities depending who is asked. And yet at the same time we can also anticipate that these subjective evaluations will drive the knowledge transfer process. This is of course the essence of problemistic search, in that it is both simple-minded (i.e. based on subjective evaluations rather than objective data) and biased (i.e. certain units will likely end up getting higher evaluations for reasons that have nothing to do with their actual capabilities).

The following matrix provides a simple graphical depiction of the likely knowledge flows that follow from the problemistic search process described above. Recall that our analysis is focused on the subsidiary unit that is potentially either a source of knowledge flows to other parts of the MNC or a recipient of knowledge flows from other units. The matrix therefore considers how other units evaluate the focal subsidiary's capabilities versus how the subsidiary evaluates itself. Where the focal subsidiary is the potential source of knowledge flows, we can expect it to be approached by other

marketing subsidiaries in this study received relatively few HQ-mandated directives, and had considerable degrees of freedom in the extent to which they engaged in corporate knowledge sharing activities. 
subsidiaries and the HQ when they evaluate its capabilities as high. These ratings do not have to be accurate, and they need not align at all with the focal subsidiary’s own ratings; rather, a high evaluation from others is sufficient to begin the knowledge transfer process.

Where the focal subsidiary is the potential recipient of knowledge flows, we expect that those rating their own capabilities highly will be the ones who tend to seek out knowledge inflows, regardless of what others think of them (note that this argument is somewhat counter-intuitive, and is developed in detail below). Taken together, these arguments suggest that the subsidiaries who engage in knowledge transfer either rate themselves highly, or are rated highly by others, or both. These units become the "in-crowd". But those subsidiaries that are rated low both by themselves and by others will tend towards isolation: they will not approach others, nor will they be approached. This is the key line of argument that links the evaluation of subsidiary capabilities with the phenomenon of subsidiary isolation.

Insert Figure 1 about here

There are of course many other factors that also affect the likelihood of a subsidiary unit to engage in internal knowledge flows. But we would expect most of these factors to actually reinforce the hypothesized split between an in-crowd of subsidiaries that engage in knowledge flows and an isolated minority. We focus in this paper on two likely factors: the frequency of communication between units and their level of reciprocity in knowledge sharing. When these factors are high, the perceptions of capabilities among those units that are already interacting with one another is likely to rise, which will further reinforce the existing pattern of interaction.

Having developed the overarching logic for why the phenomenon of subsidiary isolation emerges, we will now build the argument leading up to the specific hypotheses in more detail.

\section{Capability Perception and Subsidiary Isolation}

Consider first the case where the focal subsidiary is the source of knowledge that is being transferred either to its peers or to HQs. Gupta and Govindarajan (2000) posited that we should expect higher knowledge outflows from units with more valuable knowledge. To a certain extent we subscribe to this proposition, but the problemistic search framing offers a slightly more nuanced perspective on the hypothesized relationship. Specifically, we would argue that the recipient of the 
subsidiary's knowledge (the corporate HQ or a peer subsidiary) perceives the focal subsidiary to have high capabilities, and therefore it sees that subsidiary as potentially being able to address the problem it faces. The difference between this argument and Gupta and Govindarajan’s (2000) logic is not just semantic, because in our case knowledge flows are triggered by the perceptions of the potential recipients of the subsidiary’s knowledge, whereas in Gupta and Govindarajan’s (2000) case knowledge flows are driven by absolute levels of subsidiary capability (and are measured as such). Our proposition is also consistent with Borgatti \& Cross’s (2003:434) finding, at the individual level, that a knowledge seeker should positively evaluate the knowledge and skills of the person sought after in relation to the problem the seeker is attempting to solve. Thus, we propose formally that:

Hypothesis 1a. Higher rating of the focal subsidiary's capabilities by $\underline{\mathrm{HQ}}$ is positively associated with a high frequency of vertical knowledge outflows.

Hypothesis $1 b$. Higher rating of the focal subsidiary's capabilities by its peers units is positively associated with a high frequency of horizontal knowledge outflows.

Consider now the case where the focal subsidiary is the recipient of knowledge inflows. Here, it is less clear how the perceptions of the focal unit's capabilities will influence vertical and horizontal knowledge inflows. One line of thought would be to predict that low self-ratings would be associated with higher knowledge inflows, i.e., that units which assess their own capabilities as high would decide that they do not need more knowledge and so would engage in less knowledge inflows. In such a case, the logic of the receiving unit being perceived as having weak capabilities is consistent with the traditional logic where best practices flow from the most capable units to the less capable ones (e.g. Chew, Bresnahan and Clark, 1990; Leibenstein, 1966)².

The behavioural perspective developed in this paper leads us to make exactly the opposite prediction. That is, we expect that high self-ratings of capability will be associated with high knowledge inflows. Two sets of arguments support this proposition. First, the subsidiary which rates its own capabilities highly is likely to be more motivated to engage in knowledge inflows. This argument builds on the concept of group-efficacy — defined as a group's belief in its capability to 
perform a task objective (Bandura, 1997; Gibson, 1999, 2003; Lindsley, Brass and Thomas, 1995)— which can be a high motivator in a team. Consistent with recent multilevel theorizing, we argue that group efficacy has origins at the individual level (Bandura, 1986) and emergent properties at the group level (Kozlowski \& Klein, 2000) and we suggest that it could equally apply to the level of the subsidiary management team. Durham, Locke, Poon \& McLeod (2000) showed that group efficacy positively affects information seeking. We suggest that subsidiaries with low group-efficacy tend to be distracted by ruminations about perceived inadequacies and failures, which consumes limited cognitive resources that are needed to process task demands effectively. Conversely, those subsidiaries with high group-efficacy tend to be more focused on task requirements and less distracted by performance anxiety and off-task cognitions (Bandura, 1991, 1997) and therefore they may be better able and motivated to seek, integrate, and interpret information (Brown et al., 2001:5).

The concept of group-efficacy helps to explain why the subsidiary that rates its own capabilities highly would also be engaging in problemistic search. Essentially, greater self-belief creates a motivation for the subsidiary to improve (and therefore fulfil that self-belief), which leads to a more explicit and self-critical assessment of the subsidiary's own strengths and weaknesses. This process is likely to expose aspects of the subsidiary's activities that are not as strong as managers would like, with the result that they engage in a process of search to identify other units that can help them to improve further.

Secondly, our prediction is also consistent with the literature on absorptive capacity (Cohen and Levinthal, 1990; Lane and Lubatkin, 1998; Zahra and George, 2002). A focal unit's that rates its capability high is likely to be more able to recognize the value of other units' knowledge, and its own capacity to assimilate that knowledge. Absorptive capacity is a measure of the overall stock of knowledge in a unit, and it has been shown in many contexts that absorptive capacity increases the firm’s ability to access and make use of external knowledge (Cohen and Levinthal, 1990; Zahra and George, 2002). Lane and Lubatkin (1998) have further argued that absorptive capacity has a relational component, so that the ability to assimilate external knowledge is in part a function of the level of fit

\footnotetext{
${ }^{2}$ This would also be consistent with findings in social psychology (e.g. Weiss and Knight, 1980) where individuals with high self-esteem were reliant more on themselves than on their job environments for guidance
} 
between the interacting parties. In other words, the knowledge gap between the teacher and the student must be at threshold levels for such knowledge flows to occur (Cohen and Levinthal, 1990; Lane and Lubatkin, 1998).

Taken together, these arguments suggest the following hypotheses:

Hypothesis 2a. Higher self-rating of its capabilities by the focal unit is positively associated with a high frequency of vertical knowledge inflows.

Hypothesis $2 b$. Higher self-rating of its capabilities by the focal unit is positively associated with a high frequency of horizontal knowledge inflows.

\section{Reinforcing Subsidiary Isolation}

The first two hypotheses focused on the demand-driven aspects of problemistic search that are the core of our argument. In this section we argue that other elements of the problemistic search model (specifically levels of communication and reciprocity) play an important role in reinforcing subsidiary isolation. It should be acknowledged that these hypotheses have already been considered in other studies. They are developed here because they contribute an important part to the overarching argument explaining the existence of isolated subsidiaries.

The pattern of knowledge flows seen in the MNC is likely to take on a path-dependent form (Dosi, 1988; Nelson \& Winter, 1982), whereby the results of past searches for knowledge become the natural starting points for new searches, and subsidiary units end up relying on their own experience and established knowledge bases to determine what is important and useful (Rosenkopf \& Almeida, 2003:752) ${ }^{3}$. Viewed in this way, the relationships that form through knowledge flows are likely to lead to further interaction and a greater likelihood of further knowledge flows in the future. We expect this to occur through two mechanisms - communication and reciprocity.

First, the frequency of communication between two units makes managers in both units more aware of opportunities for leveraging competencies (e.g. Hansen, Nohria and Tierney, 1999; Hansen, 1999; Hansen and Lovas, 2004; Katz and Tushman, 1979). Individuals may also find it easier to

\footnotetext{
in task-related behaviours.

${ }^{3}$ In a very interesting study that coincidentally cites some of the firms in our sample, Johanson \& Vahlne (1977) used this same aspect of the behavioural theory of the firm (Cyert and March, 1963) to explain why the decisions
} 
contact people who work in other units to the extent that they know them or at least know their colleagues. When units seeking knowledge understand the operations of potential knowledge providers, they are more likely to identify and retrieve relevant knowledge from them. For example, when a focal unit communicates frequently with its peers it provides clues about is own operations helping other units not only to assess if the knowledge of the focal unit may be useful for them but also it raises the awareness of those units of the potential relevance of their own knowledge for the focal unit (Schulz, 2003:447).

Second, over time we would expect knowledge outflows and knowledge inflows between any two units to be correlated with one another. The argument here is based on reciprocity, that is, the idea that those subsidiaries highly involved in sharing their knowledge with others will also be active recipients of knowledge (Axelrod, 1984; Kim and Mauborgne, 1991; Kogut, 1989; Schulz, 2003). Reciprocity suggests an expectation on the part of the source unit that the favour it is providing to the recipient unit will one day be returned, and a moral obligation on the recipient unit to uphold this implicit deal (Gouldner, 1960). Schulz (2003) has shown that reciprocity plays a significant role in affecting the knowledge flows in a MNC setting. Taken together, these arguments suggest the following hypotheses. Thus:

Hypothesis3: The frequency of communication with HQ is positively associated with the level of vertical inflows (3a) and outflows (3b) of knowledge; and the frequency of communication with other subsidiaries is positively associated with the level of horizontal inflows (3c) and outflows (3d) of knowledge.

Hypothesis 4. Higher frequency of vertical knowledge outflows to HQ is positively associated with higher frequency of vertical knowledge inflows from HQ (4a) and Higher frequency of horizontal knowledge outflows from the subsidiary is positively associated with higher frequency of horizontal knowledge inflows to the subsidiary(4b). In sum, the four hypotheses suggest a number of factors that are likely to explain why subsidiary isolation tends to exist and persist. We also conjecture, although the cross-sectional nature 
of our data does not allow us to test specific hypotheses, that the patterns of knowledge flows that lead to subsidiary isolation seem to indicate that over time some subsidiaries will find themselves in selfreinforcing spirals of sending and receiving knowledge while the self-reinforcing cycle is likely to be a downward spiral for the isolated subsidiaries that neither send nor receive knowledge flows.

\section{Knowledge flows and subsidiary performance}

Our model suggests an overall pattern of knowledge flows that reinforces existing relationships and potentially leaves some subsidiaries isolated from the main flow of interactions in the MNC. We now examine the likely impact that this pattern will have on subsidiary performance. This is important because while most of the extant literature implicitly links knowledge transfer and performance, only a few studies (e.g. Brown \& Eisenhardt, 1997; Lord \& Ranft; 1998, Tsai, 2001) actually measure performance. If there is limited research shedding light on the relationship between internal knowledge transfers and performance, the impact of internal isolation on unit's performance remains practically unexamined.

For instance, although Gupta \& Govindarajan $(1991,1994)$ have indicated the existence of isolated subsidiaries they seem to be agnostic about the performance implications of subsidiary isolation. More precisely, they proposed that those isolated subsidiaries have low knowledge outflows and low knowledge inflows because they are "local innovators". These are subsidiaries that have complete local responsibility for the creation of know-how in all key functional areas but this knowledge is seen as too idiosyncratic to be of use in other countries. Similarly, according to Gupta \& Govindarajan (1991,1994), given the idiosyncratic characteristics of their markets, knowledge from other units in the MNC are also not very useful to local innovators. Gupta \& Govindarajan (1991, 1994), however, address neither theoretically nor empirically the relationship between knowledge transfers and performance, so we do not know whether subsidiaries with low levels of knowledge inflows and outflows are actually local innovators or simply are isolated from the rest of the MNC. It seems plausible to affirm that if those subsidiaries are local innovators there should not be any significant difference between their performance and that of other subsidiaries.

We argue, however, that the isolated subsidiaries are in fact in a disadvantageous position within the MNC. They are not able to take advantage of the knowledge developed by other units 
within the MNC (e.g. new products or services). In addition, we suggest that the advantages of internal knowledge transfers derive not only from the knowledge inflow itself but also from the knowledge transfer process, i.e., from the participation in an internal knowledge network. Powell et al. (1996: 142) found that biotech firms that do not engage in interorganizational collaboration agreements have a liability of unconnectedness and tend to have lower performance than those firms that have larger, more diverse alliance networks. They argue that the development of absorptive capacity, the skill at managing collaborations, the increased awareness of new projects and reputation as a valuable partner, are all serendipitous benefits of collaboration. We believe that similar mechanisms operate in knowledge transfers among units belonging to the same MNC. Therefore, we propose that units participating in knowledge transfer activities (both sending and receiving knowledge) within the MNC enjoy the serendipitous benefits described by Powell et al. (1996). Conversely, isolated subsidiaries also have a liability analogous to the idea of "liability of unconnectedness” (Powell et al., 1996) that we call "liability of internal isolation". More precisely, to be an isolated subsidiary the focal unit should be isolated both in terms of outflows and inflows both horizontally and vertically. Thus:

Hypothesis 5. Higher frequency of knowledge inflows and outflows is associated with higher performance; in other words, isolated subsidiaries will underperform subsidiaries that are not isolated.

\section{RESEARCH METHODOLOGY}

\section{Empirical setting}

The study focused on the market-facing subsidiaries—units responsible for marketing and sales activities within a particular country—of large MNCs, and in particular on their marketing capabilities - their skills in understanding and satisfying customers (Day, 1994). We argue that market-facing units lend themselves well to the study of knowledge transfer within MNCs because they serve as corporate links between customers and the major value-adding activities of the MNC, and in order to facilitate worldwide value creation they are highly dependent on knowledge transfer within the organization (Schlegelmilch \& Chini, 2003). Moreover, market-facing units are sufficiently plentiful, and diverse in age, origin, and geographic location, that they are likely to provide an appropriate context to examine the phenomenon of isolated subsidiaries. 


\section{Sample}

We approached six large MNCs headquartered in Sweden to take part in the research. Once their support had been gained, we were given a lead contact — the corporate marketing manager or the equivalent—who provided us with a list of all marketing subsidiaries around the world. The main survey consisted of two parts. The first was sent to the managers of 204 marketing subsidiaries in the six participating MNCs (Sandvik Coromant, Sandvik Steel, Ericsson, Volvo, Pharmacia and Alfa Laval Agri). The overall average subsidiary response rate was 84\% (171 responses). See Table 1. No particular geographic region was over- or under-represented in the response by the subsidiary managers. The second part of the survey was filled in by executives from corporate HQ. Our lead contact in each of the firms either filled in the survey himself/herself, or provided names of corporate managers with global or regional responsibility for marketing activities in the MNC. The average corporate response rate was $88 \%$, i.e. 22 out of 25 corporate/division managers. The two parts of the questionnaire yielded the quantitative data upon which the hypotheses in this study are tested.

Insert Table 1 about here

\section{Measures}

The bulk of the questions were attitudinal, in that they asked respondents to assess the extent to which they agreed with the question on a 1-7 Likert scale ${ }^{4}$. In addition, we also asked a number of factual questions, such as the subsidiary's year of foundation or its number of employees. Finally, we also collected some data from secondary sources, such as the geographic distance from headquarters and the income per capita in each host country.

Knowledge flows - We operationalized this construct by asking subsidiary managers about the frequency of transfers of marketing knowledge, more precisely (1) transfers of know-how about new products and new services and (2) transfers of marketing best practices, on a 1-5 likert scale (1-never; 2-less than once a year; 3-once or twice a year; 4-around 3-6 times a year; 5-more than 6 times/year). These questions were asked for four different sets of conditions: (1) inflows from peer subsidiaries

\footnotetext{
${ }^{4}$ Concerned about the possibility of common method bias, we conducted factor analysis including all the attitudinal variables that were measured by subsidiary managers. The first factor accounted for only $44 \%$ of the variance and four factors were necessary to explain $86 \%$ of the variance. If common method bias were a serious problem in our data, one factor accounting for most of the covariance in the independent and dependent variables should have emerged (Podsakoff and Organ, 1986).
} 
(horizontal knowledge inflows); (2) inflows from the MNC headquarters (vertical knowledge inflows); (3) outflows to peer subsidiaries (horizontal knowledge outflows) and (4) outflows to the headquarters (vertical knowledge outflows). For each of these knowledge flow directions, responses across the two items were averaged to yield composite measures. The means, medians, standard deviations and Cronbach alpha values are shown in Table 2.

Subsidiary performance - To avoid common method bias, we asked the corporate respondents (i.e. the subsidiary manager's boss) to rate the subsidiary's relative financial performance on three dimensions: overall sales revenue, overall market share and operating profit (where 1 =much below average, $4=$ average and $7=$ =much above average). Responses on the three items were averaged to yield a composite measure of subsidiary performance. Reliability was moderate $(0.69){ }^{5}$

Ratings of focal subsidiary capabilities -We operationalised subsidiary capabilities as their market orientation, defined as the continuous collection of information about customers' needs and competitors' capabilities and the use of this information to create superior customer value (Jaworski and Kohli, 1993; Slater \& Narver, 1995). We believe that the use of market orientation is particularly appropriate in this study because of our focus on the transfer of marketing knowledge (it certainly would have not been the best indicator of the subsidiary's capabilities if we were analysing knowledge flows between R\&D units, for instance). As we discussed above, we used three perceptual measures of market orientation: (1) the focal subsidiary's self rating of its market orientation; (2) the corporate manager's rating of the focal subsidiary's market orientation, and (3) the peers' rating about the market orientation of the focal subsidiary. The focal subsidiary's self-rating was measured using Jaworski \& Kohli’s (1993) established index. The scale had high reliability (Alpha=0.81). The corporate manager's rating of the focal subsidiary's market orientation was measured through a 3item scale which asked corporate respondents to rate, using a 1-7 Likert scale (1=much below average, 4-average and 7=much above average), each subsidiary's expertise in (1) collecting market information; (2) distributing market information and (3) analysing and acting on market information.

\footnotetext{
${ }^{5}$ We are aware that this reliability is slightly below the 0.70 minimum acceptable level. It should be taken into consideration, however, that Cronbach alpha values are quite sensitive to short-scales (i.e. it tends to be lower in scales with less than ten items) and in this case we have only a three-item scale (Hair et al., 1998:118).
} 
(Alpha $=0.92)^{6}$. The corporate respondents did not answer the questions on all 21 items because they were typically answering for ten or more different units, but we carefully explained these items to them before they assessed the subsidiary's market orientation. Finally, we measured the peers' rating of a focal subsidiary market orientation by asking each respondent unit to vote for the most capable subsidiary in (1) collecting market information; (2) distributing market information and (3) analysing and acting on market information. The peers' rating variable is the sum of all votes in the three items above received by a focal subsidiary ${ }^{7}$.

Isolated subsidiaries-This is a dummy variable that took the value of one only when the focal subsidiary met all the following criteria: it experienced (1) vertical knowledge outflows less than once a year; (2) vertical knowledge inflows less than once a year; (3) horizontal knowledge outflows less than once a year; and (4) horizontal knowledge inflows less than once a year. Note that "less than once a year" is a score of 2 on the 5-point knowledge flow scale (see above), which seemed to be a reasonable level at which to define the concept of isolation. See Tables 2 and 3. However, as described below we also tested hypothesis 5 with alternative cut-off points as a way of assessing the robustness of our results.

Communication frequency - based on a simple frequency scale where $1=$ daily and $7=$ yearly or less (see Ghoshal, 1986; Nobel \& Birkinshaw, 1998), this scale asked respondents to indicate often how they communicated with (a) HQ managers, face-to-face, to discuss operations, (b) HQ managers, through other means, to discuss operations. The responses to these two items were averaged to yield a composite measure of communication with headquarters (Alpha 0.75). The same questions were posed in relation to the communication with peer subsidiaries. Again, responses were averaged and a composite measure of communication with peer subsidiaries was created (Alpha 0.74). We reverse-

\footnotetext{
${ }^{6}$ The first item (collecting market information) reflects Jaworki \& Kohli’ s (1993) first dimension (Intelligence Generation), the second item (distributing market information) Jaworki \& Kohli’ s (1993) second dimension (Intelligence Dissemination), and the third item (analysing and acting on market information) Jaworki \& Kohli' s (1993) third and fourth dimensions (Response Design and Response Implementation).

${ }^{7}$ For example, in Ericsson we asked 25 subsidiaries to rate which of their peers was best on each of the three dimensions of marketing orientation, resulting in a number of votes between zero (i.e. a subsidiary that did not receive any vote at all) and 12 for each country subsidiary. The number of "votes" was then assigned to the subsidiary in question as the aggregate peer rating of their capability. While a more precise approach to operationalizing this construct would be possible in a dyadic research design (i.e. studying individual flows), we believe this is as precise as one could achieve with a nodal design.
} 
coded the communication items so that a higher number is associated with more frequent

communication rather than vice versa.

Control variables. Tacitness of knowledge —-we used Zander and Kogut's (1995) scale. Respondents answered the following questions about their knowledge based on a 1-7 Likert scale, where 1=strongly disagree and 7=strongly agree: (a) a manual describing how our activities are executed could be written, (b) new staff can easily learn how to perform the services that our local company offers by talking to skilled employees, (c) training new personnel is typically a quick and easy job for us, (d) new personnel with a university education can perform the services that our local company offers. Reliability for these items was moderate (Alpha $=0.67)$. Tacitness items were reverse coded so that a higher number is associated with more tacit knowledge.

Host country economic level-Different levels of economic development of the country where the focal subsidiary is hosted may affect knowledge flows from and to that subsidiary (Gupta \& Govindarajan, 2000). To control for these effects, for each host country, data on per capita income (gross national product per capita Atlas method) in 1998 (year the data for this study were collected) were obtained from the World Development Report (World Bank, 2003).

Subsidiary age - Older subsidiaries may have had more time to develop the mechanisms and relationships to share knowledge within the MNC (Birkinshaw, Nobel \& Ridderstrale, 2002). To control for this effect, we included a variable called "Subsidiary age" which is the year when data for this study were collected (1998) minus the year of the subsidiary's foundation.

Subsidiary size-Unit size may affect the frequency of intra-firm knowledge transfer (Birkinshaw et al., 2002; Hansen \& Lovas, 2004). We control for this effect by asking respondents to indicate the number of employees in the subsidiary, which we convert to a natural logarithm in order to dampen the high variability in size and achieve a more normal distribution.

Use of external expertise-In order to control for the impact of external sources of knowledge (e.g. customers, suppliers, competitors), respondents answered the following question about their use of external expertise on a 1-7 Likert scale, where $1=$ strongly disagree and $7=$ strongly agree: "We frequently draw on external expertise when we perform our activities.” 
Geographic distance-We computed the geographic distance in kilometres between the hosting city of the focal subsidiary and the city in Sweden where the MNC's headquarters were located. In order to dampen the high variability in distance and achieve a more normal distribution, the natural logarithm of the geographic distance was used in our analyses.

Validity checks-We used SAS V8 (Hatcher, 1994; Lattin, Carroll \& Green, 2003) to perform confirmatory factor analyses (CFA) to check the convergent validity (i.e. the degree to which specific items jointly load on their hypothesized constructs; Judge, 1993) and discriminant validity (Bollen, 1989, Long, 1983, Judge, 1993) of our multi-item constructs. Factor loadings varied considerably (from 0.41 to 0.98 ) but were all highly significant and corresponded to the hypothesized latent constructs. We have also computed the composite reliability for all our latent variables by dividing (a) the squared sum of the individual standardized loadings by (b) the sum of the variance of their error terms and the squared sum of the individual standardized loadings (Fornell and Larcker, 1981). Overall, the values calculated for each of our latent variables exceeded the threshold value of 0.70 (Nunally, 1978), which suggests that our measurement model demonstrates adequate internal consistency ${ }^{8}$.It is particularly important to report that our results show the discriminant validity of horizontal and vertical communications, confirming that they are two different constructs (the correlation between them is significantly less than 1.0) and that our two-factor model has a better fit than an alternative one-factor model. Akaike's information criterion (AIC; Boomsma, 2000; Hu\&Bentler, 1999) was better (that is, smaller) for our two-factor model than for one-factor model (AIC 2 -factors $=12.53$; AIC ${ }_{\text {1-factor }}=69.96$ ). More importantly, our four constructs used to describe knowledge flows (vertical knowledge outflows, horizontal knowledge outflows, vertical knowledge inflows and horizontal knowledge inflows) also have discriminant validity. As Table 3 indicates the

\footnotetext{
${ }^{8}$ There are, however, two constructs (knowledge tacitness and subsidiary performance) that are slightly below that recommended threshold (composite reliability equal to 0.65 and 0.66 respectively). This seems to indicate that our measure of knowledge tacitness is not entirely satisfactory and that future research should probably adopt other scales to measure this construct. It is worth highlighting here that in order to check the robustness of our results, we have run all our models without the knowledge tacitness variable and our results remained qualitatively the same. In the case of our subsidiary performance measure, we believe this low composite reliability seems to reflect the debate in the international business literature about the inherent difficulties in developing reliable scales for measuring subsidiary-level performance (e.g. Andersson, Forsgren and Pedersen, 2001,).
} 
correlation among the four knowledge flow factors ranged from 0.31 to 0.66 with standard errors ranging from 0.06 to 0.08 , which means that they were all significantly less than 1.0 , demonstrating adequate discriminant validity (e.g. Bagozzi, Yi \& Phillips, 1991: 436). In addition, a four-factor solution has a better fit than plausible rival models. Akaike's information criterion (AIC; Boomsma, 2000; Hu \& Bentler, 1999) was better for our four-factor model than for the one- or two-factor models (AIC $_{\text {4-factors }}=26.20$;IC $_{\text {2-factors }}=108.74$; AIC $_{1 \text {-factor }}=185.48$ ). A comparison of standardized loadings, composite reliabilities and average variances extracted between a four- and a two-factor model also confirmed the superiority of the former. Although this four-factor model of intra-firm knowledge flows has been used before in the literature (e.g. Gupta \& Govindarajan, 2000; Schulz, 2001), to the best of our knowledge, this is the first time that CFA is used to ascertain the discriminant validity of these measures.

Insert Tables 2 and 3 about here

\section{RESULTS}

Before moving on to a discussion of the hypotheses, it is useful to discuss a few descriptive statistics associated with the questionnaire data. Tables 4 and 5 contain the descriptive and frequency statistics of the four knowledge flow variables (vertical outflows and inflows and horizontal outflows and inflows). We confirmed that a significant number of subsidiaries (12.5\%) never or less than once a year was involved in any of the four types of knowledge flows (see last column in Table 5): these are the isolated subsidiaries as defined above. The correlation matrix in Table 6 also shows, as predicted, the low correlations between the three perceptions (self, corporate and peers) of a focal subsidiary's capabilities. The correlation between self-perception and corporate perception is 0.14 and between the former and peer perception is only 0.04 . Peer perception and corporate perception about a focal subsidiary’s capabilities show a stronger correlation (0.30) but still very far from 1.0.

Insert Tables 4, 5 and 6 about here

\section{Statistical Methods}

We used ordinary least squares (OLS) to test our hypotheses. We used Stata 8.0’s regression with robust standard errors to counter the effects of heterocedasticity and because multiple observations from the same host country may not be independent, we also used robust clustering 
procedure as implemented in Stata 8.0 for all our models (Williams, 2000; Wooldridge, 2002). ${ }^{9}$ To eliminate any spurious effects due to unobserved differences among firms, we included fixed firm effects by entering dummy variables for the six companies in the study ${ }^{10}$. In order to check for the effects of multicollinearity, we calculated the variance inflation factors (VIF) and none of our variables was close to the common cut-off threshold of tolerance that corresponds to a VIF above 10 (Wooldridge, 2002).

\section{Tests of Hypotheses}

Hypotheses 1 and 2 refer to the association between perceptions of a focal unit's capabilities and knowledge outflows from and inflows to that unit. In order to test those hypotheses we included in our models both the source's and the recipient's perceptions. More precisely, we posited in hypothesis 1a that a higher frequency of vertical knowledge outflows would be associated with a high rating of the focal subsidiary's capabilities by HQ, and in $1 \mathrm{~b}$ that a higher frequency of horizontal knowledge outflows would be associated with a high rating of the focal subsidiary's capabilities by its peers units. It is worth highlighting that we control for Gupta and Govindarajan's (2000) absolute measure of "value of knowledge stock" of a focal subsidiary by including in all our models the two most important proxies—subsidiary size and GNI per capita of the host country-used by them to operationalise this construct (2000:477 and 478). In Model 2, we see that HQ's rating of the focal subsidiary’s capabilities is positively and significantly $(\mathrm{p}<0.01)$ associated with vertical knowledge outflows, supporting H1a. Model 4 also shows support for H1b. Turning to hypothesis 2, we predicted that a high self-rating of its capabilities by the focal unit is associated with high knowledge inflows both from the HQs (2a) and from its peer units (2b). Models 6 and 8 provide strong support for both hypotheses.

Hypothesis 3 posited that communication with HQs and with peers was positively correlated with knowledge outflows and inflows. Model 2 in Table 7 shows that hypothesis 3a is not supported.

\footnotetext{
${ }^{9}$ We have also run the models including one dummy variable for each of the host countries in the sample. This reduced drastically the degrees of freedom of the models but the results were qualitatively the same as those presented in the next session.

${ }^{10}$ Although we acknowledge that a random effects model may in principle produce more efficient estimates, in order to obtain an unbiased estimation with such a model, it is assumed that the random error term of each cross-sectional unit is uncorrelated with any of the regressors. This is quite a strong assumption that in this specific case is more likely to be violated than not then our choice of a fixed effects model.
} 
Communication with HQ has the predicted sign, i.e., it is positively associated with vertical knowledge outflows, but it is not significant. Model 4, on the other hand, strongly supports the prediction that communication with other subsidiaries is associated with horizontal knowledge outflows, providing support for Hypothesis 3b. As Models 6 and 8 show, neither hypothesis 3c and nor 3d which predicted the association of frequency of communication with knowledge inflows was supported. Hypotheses 4a and 4b predicted that the higher the knowledge outflows from a focal subsidiary the higher the knowledge inflows to that subsidiary, both at the vertical and horizontal levels. Models 6 and 8 in Table 8 provide strong support to our hypotheses, suggesting that vertical and horizontal knowledge outflows are positively and significantly correlated to vertical and horizontal knowledge inflows, respectively.

\section{Insert Tables 7 and 8 about here}

Finally, hypothesis 5 proposed that isolated subsidiaries have lower performance than subsidiaries that are not isolated. We tested this hypothesis by introducing a dummy variable (isolated subsidiaries) that took the value of one when the subsidiary has vertical and horizontal knowledge inflows and outflows less than once a year and the value of zero otherwise, while controlling for all other variables in our model. We expected a negative and significant coefficient for that dummy variable. As Model 10 indicates, we found strong support for hypothesis $5(\mathrm{p}<0.01){ }^{11}$

\section{Insert Table 9 about here}

\section{Robustness checks}

We also performed a number of robustness checks on our results. For instance, we have run our models including measures of motivation and absorptive capacity similar to the ones used by Gupta and Govindarajan (2000) and our results remained qualitatively the same. We also tested hypothesis 5 using a continuous variable (total knowledge flows=sum of the four types of knowledge flows) instead of the dichotomous variable. This variable is positively associated with subsidiary performance although at a lower level of significance. We also tested hypothesis 5 using different cut-

\footnotetext{
11 In order to avoid common method bias (given our performance measure was provided by corporate managers) we have not included in our performance models (Models 9 and 10) the corporate managers' rating of the focal subsidiary's capabilities. If included in the model, this variable is highly significant $(\mathrm{p}<0.001)$ and our isolated variable remains significant, although less so $(\mathrm{p}<0.05)$
} 
off points to define the isolated subsidiaries dummy variable. For instance, we aggregated vertical knowledge inflows and horizontal knowledge inflows in one single variable (total inflows, Alpha 0.75) and vertical knowledge outflows and horizontal knowledge outflows in another variable (total outflows, Alpha 0.83) and used the cut-off of two (never or less than once a year) to define which subsidiaries were considered isolated. We found a significant negative effect $(\mathrm{p}<0.01)$ of the isolated subsidiaries dummy. We also tried to use the medians in each type of knowledge flows as the cut-off point. As Table 4 indicates, the median in three types of knowledge flows was 2.0 (the same cut-off point previously used) but it was 3.0 in the case of vertical knowledge inflows. Once more, the isolated subsidiaries dummy had a negative association with subsidiary but this time it is less significant $(\mathrm{p}<0.05)$.

\section{DISCUSSION}

Overall, the findings of this study support the idea that knowledge transfers between units within a MNC tend to be influenced by a demand driven process, initiated by problemistic search on the part of the recipient unit. Three broad sets of insights emerge from the research. First, we showed that not only do the three ratings (self, corporate and peer) of a focal subsidiary's capabilities vary significantly (the pairwise correlations among them are quite low, ranging from 0.04 to 0.30 ) but also that they have different impact on knowledge outflows and inflows. In the knowledge outflows models, our results supported our argument that what predicts knowledge outflows from a focal unit is not how good it believes itself to be, but rather how the recipient rates the knowledge source. In relation to knowledge inflows, both from HQs and from peer subsidiaries, it is the recipient unit's perception again that matters. Those units that perceive themselves as highly capable seem to have both the ability and the motivation to look out more frequently for external knowledge than those units with lower self-ratings of their own capabilities.

Second, this study provides empirical support for the importance of reciprocity in reinforcing existing knowledge flow patterns. We found that knowledge tends to flow to those units that frequently share their knowledge with the rest of the organisation. This is likely to end up creating a sub-group of units within the MNC that are frequently exchanging knowledge among themselves while those subsidiaries that rarely act as sources of knowledge transfers are also unlikely to receive 
knowledge from other units. We found, however, only partial support for our hypotheses about the importance of communication to knowledge outflows and inflows. Communication with HQ does not seem to have a significant impact either on vertical knowledge outflows or on vertical knowledge inflows. On the other hand, communication with peers has a significant association with horizontal knowledge outflows and with horizontal knowledge inflows, when we do not control for horizontal knowledge outflows. Taken in conjunction with the reciprocity findings, these results seem to provide two interesting insights. A focal subsidiary that communicates frequently with HQ does not necessarily engage in more vertical knowledge flows. This may be due to the fact that a certain frequency of communication with HQ is mandatory for the provision of routine information while this is not necessarily the case with other subsidiaries. On the other hand, when it comes to relationship with its peers communication seems to be a good predictor of horizontal knowledge outflows. If we refer back to our demand driven model, this may indicate that when a focal subsidiary communicates frequently with its peers it is somehow generating some demand for its knowledge.

Those results in conjunction suggest the possibility of a certain path dependence in knowledge transfers within MNCs: as units communicate more frequently and exchange knowledge between each other, they recalibrate their understanding of their capabilities and knowledge. As they update their understanding of themselves as well as of the units they are interacting with, this positively affects their probability of interacting again in the future, creating a dynamic self-reinforcing system, and with time units may tend to be locked into a limited set of units with which they interact (Borgatti \& Cross, 2003:442). It is worth noting that this argument is potentially at odds with Kogut and Zander’s (1996) social identity argument, i.e. that one of the advantages of the firm in relation to markets is that the former provides the normative territory to which members identify. Our argument, instead, is in line with a more nuanced view of social identity (Tajfel, 1982; Tajfel \& Turner, 1986), namely optimal distinctiveness theory (Brewer, 1993). According to this theory, the classification of self (in our case a MNC unit) as a member of a highly inclusive superordinate category (e.g. belonging to Ericsson) is unlikely to satisfy most units' needs for differentiation. Hence, classification at that level may motivate attention to distinctions between themselves and other category members and an active search for subgroup differentiation (Brewer, 1993), resulting in some sort of in-group / out-group 
dynamic emerging (Tajfel, 1982; Tajfel \& Turner, 1986). To the extent that this occurs, knowledge is more likely to be exchanged between those units that perceive themselves to belong to the same subgroup within the organisation, leading to frequent knowledge exchanges among units belonging to one group of subsidiaries (the in-crowd) while another group (that we labelled isolated) remains alienated from these knowledge sharing activities. Clearly these arguments cannot be verified or falsified with the focus of the current research, because we have no insights into the way that individual subsidiary units identify with other units within the MNC. However, it is interesting to speculate that many of the same patterns of interaction that would be predicted by social identity theory can actually be generated through the problemistic search process. Additional research will be needed to shed light on the extent to which social identity and optimal distinctiveness have any real bearing on the patterns of knowledge flow observed here.

Third, another major goal of this study was to investigate the impact of internal isolation on the isolated subsidiary’s performance. Evidence supported that, all other things being equal, isolated subsidiaries seem to have lower performance than those subsidiaries that are not isolated. We believe that those subsidiaries that are alienated from the knowledge transfer activities within the firm not only do not have access to the knowledge of other units within the MNC (e.g. best practices developed by another subsidiary) but also they are alienated from an information network that is a vehicle for the rapid communication of news about opportunities and obstacles. We speculate that analogous to the idea of liability of (external) unconnectedness (Powell et al., 1996) there may be a liability of internal isolation. The causal relationship between isolation and performance is not clear though. In fact, we believe that knowledge flows and performance may be self-reinforcing mechanisms, i.e., high performing subsidiaries may have the slack resources making them able to share their knowledge, while low performing subsidiaries are fighting fires and have to concentrate on their own daily activities not sharing any knowledge. Therefore, knowledge sharing provides opportunities for improved performance and improved performance providing slack resources for knowledge sharing. 


\section{Limitations and Future Research}

This study represents an effort to explore a new theoretical and empirical perspective on knowledge transfers within MNCs. Notwithstanding the robustness of our results across models and the lack of obvious symptoms of biases, we can identify some limitations of this study that should be borne in mind for future research. First, we conducted our examination at the nodal level of analysis (i.e. the subsidiary). This was useful as a means of identifying isolated subsidiaries, but it also created a problem because knowledge transfers are best observed at the level of the dyad or system (Gupta \& Govindarajan, 2000). Future research could build on this study to develop more elaborate hypotheses that could be tested at the dyadic level of analysis. Second, despite the fact that we collected some data from secondary sources (e.g. geographic distance from headquarters and the income per capita in each host country), we used perceptual instruments to measure most of our variables, notably, the extent of knowledge outflows and inflows and subsidiary performance. We should also highlight that while our study makes an important contribution in ascertaining the convergent and discriminant validity of the four types of knowledge flows very frequently used in the knowledge management literature (vertical knowledge inflows, vertical knowledge outflows, horizontal knowledge inflows and horizontal knowledge outflows), the composite reliability (Fornell and Larcker, 1981) of our knowledge tacitness and subsidiary performance factors are slightly below the desirable threshold and additional research is needed to further develop scales that can adequately measure those constructs. Finally, the test of hypotheses in a cross-sectional research design indicates association, not causality. This raises the problem of simultaneity and we suggest the results of this study be interpreted with the necessary caution, avoiding strong causal inferences from them. It would be desirable if future research could investigate why some subsidiaries are isolated from the knowledge transfers activities within the MNC using longitudinal data. A promising avenue for future research is to use longitudinal data to test if differences between "in-crowd" and "out-crowd" units tend to increase, stabilise or diminish over time. According to the principle of learning substitution (Levinthal \& March, 1993:99), for instance, and assuming that a MNC is a nested learning system, where learning occurs at several different but interrelated units at the same time, one could expect that learning in one subsidiary would potentially be a substitute for learning at another (Levinthal \& March, 1993). If this is true, with time the highly 
capable units would be increasingly involved in knowledge outflows and inflows and would substitute for learning in low capable subsidiaries, generating increasing disparities between the former and the latter. Hence, these in-crowd subsidiaries would increasingly develop their capabilities, releasing the pressure for the isolated units to adapt.

While the tendency for certain subsidiaries to become isolated is evident in our findings, it is important to note that there are ways for MNC executives to break the vicious cycle described above. From our research interviews we identified a number of approaches that were used by some of the more effective MNCs to bring the more isolated subsidiaries back into the knowledge-sharing network, and these are described here. One was the systematic development of personal networks among subsidiary managers. Isolated subsidiaries were typically given an expatriate manager who was personally well connected, and who was able to build the relationships with other units that led subsequently to knowledge sharing. A second approach was a careful recognition of language problems: one of the organisations in our sample noticed a complete lack of knowledge sharing between the large German subsidiary and its Scandinavian peers. On closer inspection, it became clear the German boss was not confident in English, so he never participated in the informal discussions that led to knowledge sharing. The solution was simply to put a proficient English-speaker in place as the deputy to the German boss.

A third and very different approach was for corporate managers to keep detailed measures of how their subsidiaries were performing on process measures as well as performance measures. These were used to overcome the gap between perceived and actual capability measures, and thereby to facilitate the process of knowledge sharing. Alfa Laval Agri, for example, held quarterly meetings of all its subsidiary managers, and it required them to share performance along multiple dimensions so that each subsidiary manager could see how his/her unit was doing against its peers. This approach helped to reduce the level of bias in internal evaluations of capability, and it opened up the knowledge sharing processes to many more subsidiaries.

\section{Conclusion}

To conclude, this study provided a fresh look at the issue of knowledge sharing in MNCs by focusing on the situation facing subsidiary units that are not involved in knowledge sharing to any 
meaningful degree. We proposed that the recipients of knowledge flows within the MNC engage in a process of problemistic search where it is their own motivation and absorptive capacity (rather than the attributes of the source unit) and their perceptions about the capabilities of those units they are sourcing knowledge from that drive the process of knowledge transfers within MNCs. This knowledge flow pattern is likely to be reinforced by a path dependent behaviour where subsidiary units tend to to privilege those other units with which they have some communication and from which they can expect some reciprocity in terms of knowledge flows. For MNCs concerned about how they might better manage their internal knowledge flows, isolated subsidiaries are a real priority, and should therefore be the focus of far more attention than they have received to date. 
FIGURE 1

Capability Evaluations and Knowledge Flows

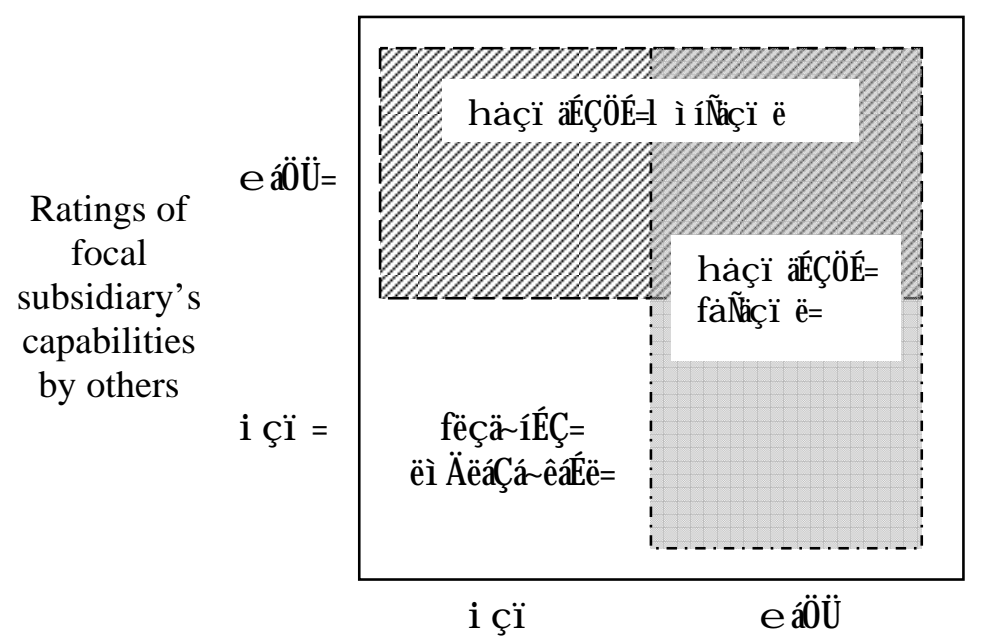

Ratings of focal subsidiary's capabilities by self

TABLE 1 Subsidiary Response Rates-Overall and by Firm

\begin{tabular}{|l|l|l|l|}
\hline & $\begin{array}{l}\text { Number } \\
\text { of units }\end{array}$ & Number of units per firm & Percent \\
\hline Initial mailing & $204^{*}$ & $\begin{array}{l}\text { Coromant 31, Steel 39, Ericsson 46, Volvo 29, } \\
\text { Pharmacia 26, Alfa Laval Agri 33 }\end{array}$ & $100 \%$ \\
\hline Non-responses & 33 & $\begin{array}{l}\text { Coromant 0, Steel 7, Ericsson 14, Volvo 4, Pharmacia } \\
\text { 7, Alfa Laval Agri 1 }\end{array}$ & $16.2 \%$ \\
\hline Responses & 171 & $\begin{array}{l}\text { Coromant 31, Steel 32, Ericsson 32, Volvo 25, } \\
\text { Pharmacia 19, Alfa Laval Agri 32 }\end{array}$ & $83.8 \%$ \\
\hline Corporate responses & $154^{* *}$ & $\begin{array}{l}\text { Coromant 27, Steel 32, Ericsson 21, Volvo 25, } \\
\text { Pharmacia 17, Alfa Laval Agri 32 }\end{array}$ & $75.5 \%$ \\
\hline
\end{tabular}

*Two units were excluded from an initial sample since one of the MNCs was closing down its operations in these countries. There were few employees left, and their motivation to participate in the study was very low. ${ }^{* *} 19$ corporate managers assessed those 154 subsidiaries. 
TABLE 2 - Factor Solutions -- Knowledge Flows (The CALIS Procedure - SAS V8)

\begin{tabular}{|l|l|}
\hline Exogenous Variables & Manifest variables loadings and t values \\
\hline f_si1:. Vertical Knowledge & Inflows of know-how about new products and new services from the \\
Inflows (VKI) & HQs \\
& 0.65 (t value=7.75) \\
\hline & Inflows of marketing best practices from the HQs \\
& 0.88 (t value=10.12) \\
\hline f_si2: Horizontal Knowledge & Inflows of know-how about new products and new services from \\
Inflows (HKI) & 0.65 (t value=8.25) \\
& Inflows of marketing best practices from other subsidiaries \\
& 0.95 (t value=12.13) \\
\hline f_si3: Vertical Knowledge & Outflows of know-how about new products and new services to the \\
Outflows (VKO) & HQs \\
& 0.72 (t value=9.83) \\
\hline & Outflows of marketing best practices to the HQs \\
& 0.97 (t value=13.92) \\
\hline f_si4: Horizontal Knowledge & Outflows of know-how about new products and new services to other \\
Outflows & subsidiaries \\
(HKO) & 0.66 (t value=8.74) \\
\hline & Outflows of marketing best practices to other subsidiaries \\
& 0.98 (t value=13.81) \\
\hline
\end{tabular}

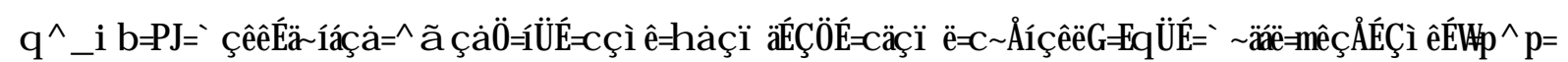
$s \cup \bar{F}=$

\begin{tabular}{|l|l|l|l|l|}
\hline & f_si1:VKI & f_si2: HKI & f_si3:VKO & f_si4: HKIO \\
\hline f_si1:VKI & --- & & & \\
\hline f_si2: HKI & 0.56 & --- & & \\
& $(0.08)$ & & & \\
\hline f_si3:VKO & 0.43 & 0.37 & --- & \\
& $(0.08)$ & $(0.08)$ & & \\
\hline f_si4: HKO & 0.31 & 0.55 & 0.66 & --- \\
& $(0.08)$ & $(0.07)$ & $(0.06)$ & \\
\hline
\end{tabular}

Gpí å Ç êC =

TABLE 4 - Descriptive Statistics - Knowledge Flows

\begin{tabular}{|l|l|l|l|l|}
\hline & Vertical K- outflows & $\begin{array}{l}\text { Horizontal K- } \\
\text { outflows }\end{array}$ & Vertical K- inflows & $\begin{array}{l}\text { Horizontal K- } \\
\text { inflows }\end{array}$ \\
\hline N valid & 167 & 165 & 164 & 165 \\
\hline Mean & 2.18 & 2.18 & 3.01 & 2.30 \\
\hline Median & 2.00 & 2.00 & 3.00 & 2.00 \\
\hline Standard Deviation & 1.01 & .90 & .932 & .956 \\
\hline Cronbach Alpha & 0.82 & 0.79 & 0.73 & 0.77 \\
\hline
\end{tabular}


TABLE 5 - Frequency Statistics - Knowledge Flows

\begin{tabular}{|l|l|l|l|l|l|}
\hline $\begin{array}{l}\text { Frequency of } \\
\text { knowledge flows }\end{array}$ & $\begin{array}{l}\text { Vertical K- } \\
\text { inflows }\end{array}$ & $\begin{array}{l}\text { Horizontal K- } \\
\text { inflows }\end{array}$ & $\begin{array}{l}\text { Vertical K- } \\
\text { outflows }\end{array}$ & $\begin{array}{l}\text { Horizontal K- } \\
\text { outflows }\end{array}$ & $\begin{array}{l}\text { All four types of } \\
\text { knowledge flows }\end{array}$ \\
\hline $\begin{array}{l}\text { Never or less than } \\
\text { once a year }\end{array}$ & $21.3 \%$ & $53.9 \%$ & $53.3 \%$ & $58.2 \%$ & $12.5 \%$ \\
\hline $\begin{array}{l}\text { More than once a } \\
\text { year }\end{array}$ & $78.7 \%$ & $46.1 \%$ & $46.7 \%$ & $41.8 \%$ & $87.5 \%$ \\
\hline
\end{tabular}


TABLE 6 Descriptive Statistics and Correlation matrix

\begin{tabular}{|c|c|c|c|c|c|c|c|c|c|c|c|c|c|c|c|c|c|c|c|c|c|c|c|c|c|}
\hline & $\mathrm{N}$ & Mean & S.D. & 1 & 2 & 3 & 4 & 5 & 6 & 7 & 8 & 9 & 10 & 11 & 12 & 13 & 14 & 15 & 16 & 17 & 18 & 19 & 20 & 21 & 22 \\
\hline 1 Vertical oufflow & 167 & 2.18 & 2.03 & 1.00 & & & & & & & & & & & & & & & & & & & & & \\
\hline 2 Vertical inflow & 164 & 3.01 & 1.86 & 0.39 & 1.00 & & & & & & & & & & & & & & & & & & & & \\
\hline 3 Horizontal oufflow & 165 & 2.18 & 1.80 & 0.63 & 0.26 & 1.00 & & & & & & & & & & & & & & & & & & & \\
\hline 4 Horizontal inflow & 165 & 2.30 & 1.91 & 0.30 & 0.45 & 0.44 & 1.00 & & & & & & & & & & & & & & & & & & \\
\hline 5 Isolated subsidiaries & 168 & 0.13 & 0.33 & -0.38 & -0.55 & -0.38 & -0.34 & 1.00 & & & & & & & & & & & & & & & & & \\
\hline 6 Performance & 154 & 4.10 & 1.33 & 0.33 & 0.03 & 0.36 & 0.00 & -0.14 & 1.00 & & & & & & & & & & & & & & & & \\
\hline 7 Market orientation (corporate rating) & 154 & 4.42 & 1.35 & 0.28 & -0.07 & 0.29 & -0.12 & -0.07 & 0.65 & 1.00 & & & & & & & & & & & & & & & \\
\hline 8 Market orientation (subsidiary rating) & 171 & 4.41 & 0.73 & 0.15 & 0.21 & 0.28 & 0.32 & -0.11 & 0.17 & 0.14 & 1.00 & & & & & & & & & & & & & & \\
\hline 9 Market orientation (peer rating) & 171 & 0.90 & 2.52 & 0.20 & 0.10 & 0.20 & -0.01 & -0.10 & 0.33 & 0.30 & 0.04 & 1.00 & & & & & & & & & & & & & \\
\hline 10 Communication with sub & 169 & 2.95 & 1.19 & 0.09 & 0.10 & 0.24 & 0.20 & -0.10 & 0.20 & 0.14 & 0.26 & 0.09 & 1.00 & & & & & & & & & & & & \\
\hline 11 Communication with $\mathrm{HQ}$ & 169 & 3.41 & 1.34 & 0.14 & 0.13 & 0.09 & 0.07 & -0.10 & 0.09 & 0.03 & 0.13 & 0.10 & 0.37 & 1.00 & & & & & & & & & & & \\
\hline 12 Geographical distance (In) & 161 & 7.53 & 1.14 & -0.29 & -0.07 & -0.29 & -0.09 & 0.03 & -0.35 & -0.22 & -0.09 & $0.12-$ & $-0.25-c-c-c-5$ & $-0.07 \quad 1-10$ & 1.00 & & & & & & & & & & \\
\hline 13 Age & 154 & 27.63 & 23.06 & 0.27 & 0.15 & 0.26 & 0.07 & -0.12 & 0.29 & 0.29 & 0.14 & 0.06 & 0.05 & $0.02-c$ & $-0.18 \quad 1$ & 1.00 & & & & & & & & & \\
\hline 14 Tacitness & 171 & 4.36 & 0.82 & 0.12 & -0.08 & 0.13 & -0.08 & 0.16 & 0.08 & 0.24 & 0.27 & -0.05 & $0.04-c$ & $-0.07-c$ & $-0.20 \mathrm{c}-2-3-1$ & $0.04 \quad 1$ & 1.00 & & & & & & & & \\
\hline 15 Use of external expertise & 170 & 3.48 & 1.70 & -0.07 & -0.05 & -0.10 & 0.01 & 0.02 & 0.04 & 0.10 & 0.03 & 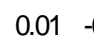 & -0.03 & $0.15-c$ & $-0.02-c$ & $-0.09-c$ & -0.051 & 1.00 & & & & & & & \\
\hline 16 Size (In employee) & 166 & 3.96 & 1.50 & 0.27 & -0.06 & 0.27 & -0.05 & -0.03 & 0.45 & 0.36 & 0.01 & 0.19 & $0.01-c$ & $-0.04-c$ & $-0.12 \mathrm{c} \quad \mathrm{c}-\mathrm{c}$ & $0.31 \mathrm{c}-\mathrm{c}-2$ & 0.000 & 0.02 & 1.00 & & & & & & \\
\hline 17 Gni per capita host country & 157 & 19129.87 & 11724.50 & 0.25 & -0.03 & 0.19 & -0.06 & -0.08 & 0.47 & 0.45 & -0.01 & 0.19 & 0.170 & $0.09-0$ & -0.370 & 0.260 & $0.06-0$ & -0.01 & 0.23 & 1.00 & & & & & \\
\hline 18 dumsteel & 171 & 0.19 & 0.39 & 0.02 & 0.05 & -0.03 & 0.03 & -0.14 & -0.19 & -0.06 & 0.04 & 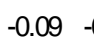 & $-0.20-0$ & $-0.16 \quad 0$ & 0.080 & $0.10-0$ & $-0.02 \quad 0$ & $0.11-0$ & $-0.33-0$. & -0.06 & 1.00 & & & & \\
\hline 19 dumcorom & 171 & 0.18 & 0.39 & -0.05 & 0.25 & -0.03 & -0.10 & -0.13 & 0.00 & -0.03 & 0.02 & $-0.02-1-x-y-1$ & $-0.06-0$ & $-0.04 \quad 0$ & 0.050 & 0.150 & 0.050 & 0.120 & $0.06-0$ & $-0.01-0$. & -0.23 & 1.00 & & & \\
\hline 20 dumerics & 171 & 0.19 & 0.39 & 0.01 & -0.05 & -0.14 & -0.17 & 0.05 & 0.13 & 0.04 & -0.17 & -0.11 & 0.050 & 0.100 & $0.04-0$ & $-0.23-0$ & $-0.03-0$ & $-0.08 \quad 0$ & $0.13-0$. & $-0.04-0$. & $-0.23-0$. & -0.23 & 1.00 & & \\
\hline 21 dumvolvo & 171 & 0.15 & 0.35 & -0.09 & -0.18 & -0.02 & 0.10 & 0.15 & -0.05 & 0.24 & 0.09 & 0.00 & 0.220 & $0.17-0$ & $-0.13-0$ & $-0.06 \quad 0$ & 0.12 & $0.18-0$ & $-0.06 \quad 0$ & $0.09-0$. & $-0.20-0$. & $-0.19-0$ & -0.20 & 1.00 & \\
\hline 22 dumpharm & 171 & 0.11 & 0.32 & -0.12 & -0.30 & 0.06 & -0.02 & 0.26 & 0.07 & -0.04 & -0.04 & $-0.10-(-y-2-y$ & $-0.03-0$ & $-0.24-0$ & $-0.05-0$ & $-0.11 \quad 0$ & 0.00 & $0.08 \quad 0$ & 0.30 & $0.03-0$. & $-0.17-0$. & $-0.17-0$ & -0.17 & -0.15 & 1.00 \\
\hline 23 dumagri & 171 & 0.19 & 0.39 & 0.20 & 0.15 & 0.18 & 0.17 & -0.13 & 0.07 & -0.14 & 0.06 & 0.30 & 0.04 & $0.14-0$ & -0.01 & $0.11-0$ & -0.10 & $0.16-0$ & -0.05 & $0.00-0$. & $-0.23-0$. & $-0.23-0$ & -0.23 & -0.2 & \\
\hline
\end{tabular}


TABLE 7 Results of Regression Analysis of Vertical and Horizontal Knowledge Outflows

\begin{tabular}{|c|c|c|c|c|}
\hline \multirow[t]{2}{*}{ Variable } & Model 1 & Model 2 & Model 3 & Model 4 \\
\hline & Vertical Outflows & Vertical Outflows & Horizontal Outflows & Horizontal Outflows \\
\hline $\begin{array}{l}\text { Market orientation capabilities } \\
\text { (corporate rating) }\end{array}$ & - & $\begin{array}{c}0.32^{* *} \\
(0.14) \\
{[1.81]}\end{array}$ & - & - \\
\hline $\begin{array}{l}\text { Market orientation capabilities } \\
\text { (self rating) }\end{array}$ & - & $\begin{array}{c}0.16 \\
(0.20) \\
{[1.17]}\end{array}$ & - & $\begin{array}{c}0.18 \\
(0.21) \\
{[1.26]}\end{array}$ \\
\hline $\begin{array}{l}\text { Market orientation capabilities } \\
\text { (peer rating) }\end{array}$ & - & - & - & $\begin{array}{l}0.09 * * \\
(0.04) \\
{[1.25]}\end{array}$ \\
\hline Communication with HQ & - & $\begin{array}{c}0.20 \\
(0.13) \\
{[1.27]}\end{array}$ & - & - \\
\hline $\begin{array}{l}\text { Communication with } \\
\text { subsidiaries }\end{array}$ & - & - & - & $\begin{array}{c}0.50 * * * \\
(0.12) \\
{[1.32]}\end{array}$ \\
\hline $\begin{array}{l}\text { Ln geographic distance } \\
\text { (from HQ) }\end{array}$ & - & $\begin{array}{c}-0.31 * * \\
(0.14) \\
{[1.26]}\end{array}$ & - & - \\
\hline Age & $\begin{array}{c}0.00 \\
(.01) \\
{[1.44]}\end{array}$ & $\begin{array}{c}0.00 \\
(.01) \\
{[1.51]}\end{array}$ & $\begin{array}{c}0.01 \\
(.00) \\
{[1.45]}\end{array}$ & $\begin{array}{c}0.01 \\
(0.00) \\
{[1.52]}\end{array}$ \\
\hline Tacitness & $\begin{array}{c}0.26 \\
(0.20) \\
{[1.08]}\end{array}$ & $\begin{array}{c}0.36 \\
(0.25) \\
{[1.28]}\end{array}$ & $\begin{array}{c}0.22 \\
(0.16) \\
{[1.08]}\end{array}$ & $\begin{array}{c}0.22 \\
(0.14) \\
{[1.18]}\end{array}$ \\
\hline Size (lnemployee) & $\begin{array}{c}0.45 * * * \\
(0.13) \\
{[1.63]}\end{array}$ & $\begin{array}{l}0.38 * * \\
(0.15) \\
{[1.85]}\end{array}$ & $\begin{array}{l}0.30 * * \\
(0.12) \\
{[1.61]}\end{array}$ & $\begin{array}{c}0.31 * * * \\
(0.10) \\
{[1.76]}\end{array}$ \\
\hline Gni per capita (host country) & $\begin{array}{c}0.00 \\
(0.00) \\
{[1.14]}\end{array}$ & $\begin{array}{l}-0.00 \\
(0.00) \\
{[1.48]}\end{array}$ & $\begin{array}{c}0.00 \\
(0.00) \\
{[1.14]}\end{array}$ & $\begin{array}{l}-0.00 \\
(0.00) \\
{[1.23]}\end{array}$ \\
\hline Use external expertise & $\begin{array}{l}-0.07 \\
(0.10) \\
{[1.19]}\end{array}$ & $\begin{array}{l}-0.08 \\
(0.08) \\
{[1.24]}\end{array}$ & $\begin{array}{l}-0.09 \\
(0.09) \\
{[1.18]}\end{array}$ & $\begin{array}{c}-0.16 * * \\
(0.07) \\
{[1.22]}\end{array}$ \\
\hline _cons & $\begin{array}{l}-0.16 \\
(1.32)\end{array}$ & $\begin{array}{c}2.05 \\
(2.28)\end{array}$ & $\begin{array}{c}2.35 \\
(1.29)\end{array}$ & $\begin{array}{c}0.63 \\
(1.16)\end{array}$ \\
\hline $\begin{array}{l}\text { Firm effects (joint test) } \\
\text { F }\end{array}$ & $\begin{array}{c}* * \\
3.29 * *\end{array}$ & $\begin{array}{c}* \\
7.08 * * *\end{array}$ & $\begin{array}{l}\text { Not Sig. } \\
6.13^{* * *}\end{array}$ & $\begin{array}{l}\text { Not Sig. } \\
10.10^{* * *}\end{array}$ \\
\hline$\Delta \mathrm{F}$ & - & $6.83^{* * *}$ & - & $10.55^{* * *}$ \\
\hline$R 2$ & 0.21 & 0.33 & 0.21 & 0.35 \\
\hline Adjusted R2 & 0.15 & 0.24 & 0.15 & 0.28 \\
\hline$\Delta$ in Adjusted R2 & - & 0.09 & - & 0.13 \\
\hline$N$ & 138 & 119 & 136 & 136 \\
\hline
\end{tabular}


TABLE 8 Results of Regression Analysis of Vertical and Horizontal Knowledge Inflows

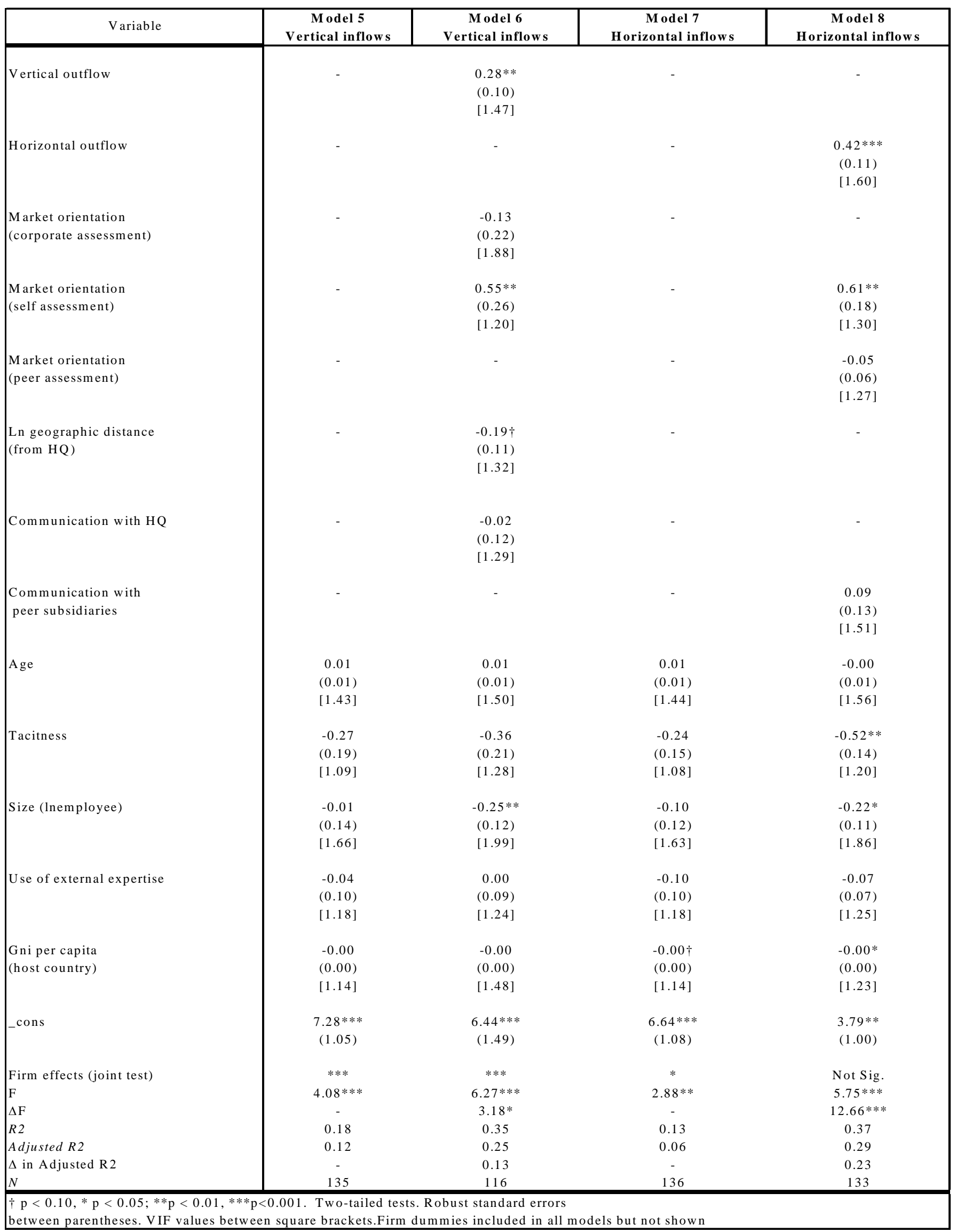


TABLE 9 Results from Regression Analysis of Subsidiary Performance

\begin{tabular}{|c|c|c|}
\hline Variable & Model 9 & Model 10 \\
\hline Isolated subsidiaries dummy & - & $\begin{array}{c}-0.89 * * \\
(0.33) \\
{[1.24]}\end{array}$ \\
\hline $\begin{array}{l}\text { Market orientation } \\
\text { (peer assessment) }\end{array}$ & $\begin{array}{c}0.17 * * \\
(0.06) \\
{[1.21]}\end{array}$ & $\begin{array}{l}0.17 * * \\
(0.06) \\
{[1.19]}\end{array}$ \\
\hline $\begin{array}{l}\text { Market orientation } \\
\text { (subsidiary assessment) }\end{array}$ & $\begin{array}{c}0.17 \\
(0.12) \\
{[1.52]}\end{array}$ & $\begin{array}{c}0.13 \\
(0.11) \\
{[1.28]}\end{array}$ \\
\hline Communication with HQ & $\begin{array}{l}-0.00 \\
(0.07) \\
{[1.41]}\end{array}$ & $\begin{array}{l}-0.02 \\
(0.07) \\
{[1.42]}\end{array}$ \\
\hline $\begin{array}{l}\text { Communication with } \\
\text { peer subsidiaries }\end{array}$ & $\begin{array}{c}0.05 \\
(0.09) \\
{[1.66]}\end{array}$ & $\begin{array}{c}0.02 \\
(0.09) \\
{[1.69]}\end{array}$ \\
\hline Age & $\begin{array}{c}0.00 \\
(0.00) \\
{[1.48]}\end{array}$ & $\begin{array}{l}0.01 \dagger \\
(0.00) \\
{[1.48]}\end{array}$ \\
\hline $\begin{array}{l}\text { Ln geographic distance } \\
\text { (from HQ) }\end{array}$ & $\begin{array}{l}-0.16 \dagger \\
(0.09) \\
{[1.32]}\end{array}$ & $\begin{array}{l}-0.16 \dagger \\
(0.09) \\
{[1.32]}\end{array}$ \\
\hline Tacitness & $\begin{array}{c}0.12 \\
(0.09) \\
{[1.25]}\end{array}$ & $\begin{array}{l}0.19 \dagger \\
(0.11) \\
{[1.30]}\end{array}$ \\
\hline Size (lnemployee) & $\begin{array}{l}0.20^{*} \\
(0.09) \\
{[2.12]}\end{array}$ & $\begin{array}{l}0.18 \dagger \\
(0.09) \\
{[2.04]}\end{array}$ \\
\hline Use of external expertise & $\begin{array}{c}0.07 \\
(0.06) \\
{[1.33]}\end{array}$ & $\begin{array}{c}0.07 \\
(0.06) \\
{[1.32]}\end{array}$ \\
\hline $\begin{array}{l}\text { Gni per capita } \\
\text { (host country) }\end{array}$ & $\begin{array}{c}0.00 * * * \\
(0.00) \\
{[1.47]}\end{array}$ & $\begin{array}{l}0.00 * * \\
(0.00) \\
{[1.41]}\end{array}$ \\
\hline _cons & $\begin{array}{l}1.75 \dagger \\
(0.91)\end{array}$ & $\begin{array}{l}1.78 \dagger \\
(0.93)\end{array}$ \\
\hline Firm effects (joint test) & $*$ & Not Sig. \\
\hline $\begin{array}{l}\mathrm{F} \\
\Delta \mathrm{F} \\
R 2 \\
\text { Adjusted } R 2 \\
\Delta \text { in Adjusted R2 } \\
N\end{array}$ & $\begin{array}{c}30.06 * * * \\
- \\
0.49 \\
0.42 \\
- \\
120\end{array}$ & $\begin{array}{c}29.60 * * * \\
8.68 * * \\
0.52 \\
0.44 \\
0.02 \\
119\end{array}$ \\
\hline
\end{tabular}




\section{References}

Adner, R. \& Levinthal, D. 2001. Demand Heterogeneity and Technology Evolution: Implications for Product and Process Innovation. Management Science, Vol. 47 Issue 5, 611-628.

Allen, T. J. 1977. Managing the Flow of Technology: Technology Transfer and the Dissemination of Technological Information Within the R\&D Organization. MIT Press: Cambridge, MA.

Almeida, P., Song, J. \& Grant, R.M. 2002. Are Firms Superior to Alliances and Markets? An Empirical Test of Cross-Border Knowledge Building. Organization Science, 13, 2: 147-161.

Andersson, U.; Forsgren, M. \& Pedersen, T. 2001. Subsidiary performance in multinational corporations: the importance of technology embededness. International Business Review, 10: 3-23.

Axelrod, R. 1984. The Evolution of Cooperation. Basic Books: New York.

Bagozzi, R.P.; Yi, Y. \& Phillips, L.W. 1991. Assessing Construct Validity in Organizational Research. Administrative Science Quarterly, 36: 421-458.

Bandura, A. 1986. Social foundations of thought and action: A social cognitive theory. Englewood Cliff, NJ: Prentice Hall.

Bandura, A. 1991. Social cognitive theory of self-regulation. Organizational Behavior and Human Decision Processes, 50, 248-287.

Bandura, A. 1997. Self-efficacy: The exercise of control. New York: Freeman

Bartlett, C. \& Ghoshal, S. 1989 Managing across borders: The Transnational Solution. Boston, MA: Harvard Business School Press.

Birkinshaw, J., Holm, U., Thilenius, P. \& Arvidsson, N. 2000. Consequences of perceptions gaps in headquarters-subsidiary relationship. International Business Review; Vol. 9 Issue 3, 321344.

Birkinshaw, J., Nobel, R. \& Ridderstrale, J. 2002. Knowledge as a contingency variable: do characteristics of knowledge predict organizational structure? Organization Science, Vol. 13 (3), 274-289.

Bollen, K.A. 1989. Structural equations with latent variables. New York: Willey

Boomsma, A. 2000. Reporting analyses of covariance structures. Structural Equation Modelling, 7: 461-483.

Boomer, W.H., Johnson, J.L., Podsakoff, G.A. Mackenzie, P.M. 1995. On the interchangeability of objective and subjective measures of employee performance: A meta-analysis. Personnel Psychology. 48(3), 587-605.

Borgatti, S. P. \& Cross, R. 2003. A Relational View of Information Seeking and Learning in Social Networks. Management Science, Vol. 49, 4, 432-445.

Brewer, M.B. 1993. Social identity, distinctiveness, and in-group homogeneity. Social cognition, 11 (1), 150-164

Brown, S.L. \& Eisenhardt, K.M. 1997. The art of continuous change: linking complexity theory and time-paced evolution in relentlessly shifting organizations. Administrative Science Quarterly, 42:1-34.

Brown, S., Ganesan S., Challagalla, G. 2001. Self Efficacy as a moderator of information-seeking effectiveness. Journal of Applied Psychology, 86, 1043-1051

Buckley, P.J. \& Casson, M. 1976. Alternative theories of the multinational enterprise. Chapter 3 in The Future of the Multinational Enterprise. London: MacMillan.

Caves, R. E. 1971. International corporations: The industrial economics of foreign investment. Economica, 38, 1-27.

Chew, W.B.; Bresnahan, T.F; \& K.B.Clark. 1990. Measurement, coordination and learning in a multiplant network. In R.S. Kaplan (Eds.), Measures for manufacturing excellence. 129-162. Boston, HBS.

Cohen, W.M., \& Levinthal, D.A. 1990. Absorptive Capacity: A New Perspective on Learning and Innovation. Administrative Science Quarterly, 35.

Cyert, R.M. and March, J.G. 1963. Behavioral theory of the firm. New Jersey: Prentice Hall Inc., Englewood Cliffs.

Davenport, T.H \& Prusak L. 1998.Working Knowledge: Managing What Your Organization Knows. Harvard Business School Press, Boston, MA.

Day, G.S. 1994. The Capabilities of Market-Driven Organizations. Journal of Marketing, 58, 4:37-52. 
DeCarolis, D., \& Deeds, D.L. 1999. The impact of stocks and flows of organizational knowledge on firm performance: An empirical investigation of the biotechnology industry. Strategic Management Journal, 20: 953-968

Denrell, J., Arvidsson, N. \& Zander, U. 2004. Knowledge Management in the dark: An empirical study of the reliability of capability evaluations. Management Science, 50 (11), 1491-1503.

Dosi, G. 1988. Sources, procedures, and microeconomic effects of innovation. Journal of Economic Literature, 26: 1120-1171

Durham, C., Locke, E., Poon, J \& McLeod, P. 2000. Effects of group goals and time pressure on group efficacy, information-seeking strategy, and performance. Human Performance, 13(2), 115-138

Eisenhardt, K.M. \& Santos, F.M. 2002. Knowledge-Based View: A New Theory of Strategy? In A. Pettigrew, H. Thomas, \& R. Whittington (Eds.), Handbook of Strategy and Management: 139-164. London, UK: Sage.

Fornell, C. \& Larcker, D.F. 1981. Evaluating Structural Equation Models with Unobservable Variables and Measurement Error. Journal of Marketing Research. 18: 39-50.

Galunic, C. \& Rodan, S. 1998. Resource combinations in the firm: Knowledge structures and the potential for Schumpeterian innovation. Strategic Management Journal, 19, 1193-1201.

Ghoshal, S. 1986. The innovative multinational: a differentiated network of organizational roles and management processes. Unpublished doctoral dissertation, Harvard Business School.

Ghoshal, S. \& Bartlett, C. A. 1988. Creation, Adoption and Diffusion of Innovations by Subsidiaries of Multinational Corporations. Journal of International Business Studies, Vol. 19, Issue 3, 365-388.

Ghoshal, S. \& Nohria N. 1989. Internal differentiation within multinational corporations. Strategic Management Journal, 10: 323337.

Gibson, C. 1999. Do they do what they believe they can? Group efficacy and group effectiveness across tasks and cultures. Academy of Management Journal, 42, 138-152.

Gibson, C.B. 2003. The efficacy advantage: Factors influencing the formation of group efficacy across cultures. Journal of Applied Social Psychology, 33(10): 2153-2186.

Gouldner, A.W. 1960. The norm of reciprocity: A preliminary statement. American Sociological Review, 25: 161-178

Gupta, A.K. \& Govindarajan, V. 1991. Knowledge flows and the structure of control within multinational corporations. Academy of Management Review, 16(4), 768-792

Gupta, A. K. \& Govindarajan, V. 2000. Knowledge Flows Within Multinational Corporations. Strategic Management Journal. Vol.21: 473-496

Hair, J., Anderson, R., Tatham, R. \& Black, W. 1998. Multivariate data analysis. 4th ed., Prentice Hall, New Jersey

Hansen, M.T. 1999. The search-transfer problem: the role of weak ties in sharing knowledge across organizational subunits. Administrative Science Quarterly, 44 (1), 82-111.

Hansen. M.T. \& Haas, M.R. 2001. Competing for attention in knowledge markets: electronic document dissemination in a management consulting company. Administrative Science Quarterly, 46(1): 1-28.

Hansen, M.T. \& Lovas, B. 2004. Leveraging Technological Competences. Strategic Management Journal, 25: 801-822.

Hansen, M.T., Nohria, N. \& Tierney, T. 1999. What’s your strategy for managing knowledge? Harvard Business Review, 77(2), 106-116.

Harris, M.H. \& Schaubroeck. 1988. A meta-analysis of self-supervisor, self-peer, and peer-supervisor ratings. Personnel Psychology. 41, 43-62.

Hatcher, L. 1994. A Step-by-Step Approach to Using SAS for Factor Analysis and Structural Equation Modeling, SAS Publishing,Cary, NC.

Hu, L. \& Bentler, P.M. 1999. Cutoff criteria for fit indexes in covariance structure analysis: Conventional criteria versus new alternatives. Structural Equation Modelling, 6: 1-55

Hymer, S.H. 1960. The International Operations of National Firms: A Study of Direct Foreign Investment. MIT Press, Cambridge, MA.

Jaworski, B.J. \& Kohli, A.K. 1993. Market Orientation: Antecedents and Consequences. Journal of Marketing, 57, July, pp. 53-70. 
Johanson, J. \& Vahlne, J. 1977. The Internationalization Process of the Firm $3 / 4$ A Model of Knowledge Development and Increasing Foreign Market Commitments. Journal of International Business Studies 8, 23-32

Judge, T.A. 1993. Validity of the dimensions of the pay satisfaction questionnaire: Evidence of differential prediction. Personnel Psychology, 46: 331-356.

Katz, R. \& Tushman, M. 1979. Communication patterns, project performance, and task characteristics: an empirical evaluation and integration in an R\&D setting.Management Science, 23: 139-162.

Kim, W. C. \& Mauborgne, R.A. 1991. Implementing Global Strategies: The Role of Procedural Justice. Strategic Management Journal, Vol. 12 Issue 4, 125-143.

Kogut, B. 1989. A note on global strategies. Strategic Management Journal. 12 (Summer Special Issue), 125-143.

Kogut, B. 1989. The stability of joint ventures: Reciprocity and competitive rivalry. Journal of Industrial Economics. 38(2): 183-198.

Kogut, B. \& Zander, U. 1992. Knowledge of the firm, combinative capabilities, and the replication of technology. Organization Science. 3 : 383-397

Kogut, B. \& Zander. U. 1996. What firms do? Coordination, identity, and learning. Organization Science 7(5): 502-518

Kozlowski, S.W.J., \& Klein, K.J. 2000. A multilevel approach to theory and research in organizations: Contextual, temporal and emergent processes. In K.J. Klein and S.W.J. Kozlowski (Eds.) Multilevel theory research and methods in organizations: Foundations, extensions and new directions: 3-90. San Francisco: Jossey-Bass.

Lattin, J., Carroll, J.D., Green, P.E. 2003. Analyzing Multivariate Data. Brooks/Cole-Thomson Learning, Pacific Grove, CA.

Leibenstein, H. 1966. Allocative Efficiency vs. "X-Efficiency". The American Economic Review, 56 (June), 392-415.

Levinthal \& March. 1993. Myopia of Learning. Strategic Management Journal. Vol.14 (Special Issue): 95-112

Lindsley, D.H., Brass D.J., \& Thomas, J.B. 1995. Efficacy - performance spirals: A multilevel perspective. Academy of Management Review, 20: 645-678.

Lord, M.D. \& Ranft, A.L. 1998. Transfer and sharing of local knowledge within the firm\&ntry into new international markets. Academy of Management Best Papers Proceedings'98.

March, J.G \& Simon, H.A. 1958. Organizations. New York: Wiley.

Nobel, R. \& Birkinshaw, J. 1998. Innovation in multinational corporations: control and communication patterns in R\&D operations. Strategic Management Journal, Vol. 19, 5, 479496.

Nohria, N. \& Ghoshal, S. 1997. The Differentiated Network: Organizing Multinational Corporations for Value Creation. Jossey Bass, San Francisco, CA.

Nunnally, J.C. 1978. Psychometric theory. McGraw-Hill: New York

Podsakoff, P.M., \& D.W. Organ. 1986. "Self-Reports in Organizational Research.” Journal of Management, 12 (No.4): 531-544

Powell, W.W.; Koput, K.W. \& Smith-Doerr, L. 1996. Interorganizational Collaboration and the Locus of Innovation: Networks of Learning in Biotechnology. Administrative Science Quarterly. Vol.41, No.1: 116-145.

Schlegelmilch, B. \& Chini, T.C. 2003. Knowledge transfer between marketing functions in multinational companies: a conceptual model. International Business Review, 12, 215-232.

Schmookler, Jacob.1965. Technological change and economic theory. American Economic Review, Vol. 55 Issue 2, 333-341.

Schulz, M. 2001 The Uncertain Relevance of Newness: Organizational Learning and Knowledge Flows. Academy of Management Journal; Vol. 44 Issue 4, 661-681.

Schulz, M. 2003. Pathways of Relevance: Exploring Inflows of Knowledge into Subunits of Multinational Corporations. Organization Science. Vol.14, No.4: 440-459.

Simon, H. 1947. Administrative Behavior: A Study of Decision-making Processes in Administrative Organization. Macmillan: New York 
Slater, S.F. \& Narver, J.C. 1995. Market Orientation and Organizational Learning, Journal of Marketing, Vol. 59, 63-74.

Sorenson O. \& Stuart T.E. 2001. Syndication Networks and the Spatial Distribution of Venture Capital Investments. American Journal of Sociology. Vol.106, No.6: 1546-1588.

Stewart, T. A. 1998. Intellectual capital: The New Wealth of Organizations. New York: Currency/Doubleday.

Szulanski, G. 1995. Appropriating rents from existing knowledge: intra-firm transfer of best practices. Doctoral Dissertation. INSEAD

Szulanski, G. 1996. Exploring Internal Stickiness: Impediments to the Transfer of Best Practice Within the Firm. Strategic Management Journal. Vol.17, Special Issue: 27-43.

Tajfel, H. 1982. Social psychology of intergroup relations. Annual Review of Psychology, 33, 1-39

Tajfel, H., \& Turner, J.C. 1986. The social identity theory of intergroup behaviour. In S. Worchel and W.G. Austin (eds.), Psychology of Intergroup Relations: 7-24. Chicago: Nelson-Hall.

Teece, D. J. 1981.The market for know-how and the efficient international transfer of technology, Annals, AAPSS, 458, 81-96.

Tsai, W. \& Ghoshal, S. 1998. Social capital and value creation: The role of intrafirm networks. Academy of Management Journal, Vol. 41 Issue 4, 464-476.

Tsai, W. 2001. Knowledge Transfer in Intraorganizational Networks: Effects of Network Position and Absorptive Capacity on Business Unit Innovation and Performance. Academy of Management Journal. Vol.44, No.5: 996-1004.

Weiss, H.M \& Knight, P.A. 1980. The utility of humility: Self-esteem, information search, and problem solving efficiency. Organizational Behaviour and Human Performance, 25, 216223.

Westney, D. E. 1993. Institutionalization theory and the MNC. In S. Ghoshal \&

E. D. Westney, eds., Organization theory and the multinational corporation. New York: St. Martin's Press.

Williams, R. L. 2000. A note on robust variance estimation for cluster-correlated data. Biometrics 56: 645-646.

Wooldridge, J. M. 2002. Econometric Analysis of Cross Section and Panel Data. The MIT Press, Cambridge, Massachusetts

World Bank, 2003. World Development Report.

Zahra, S. and G. George. 2002. Absorptive capacity: A review, reconceptualization and extension. Academy of Management Review. 27(2): 185-203.

Zander, U. \& Kogut, B. 1995. Knowledge and the Speed of Transfer and Imitation of Organizational Capabilities: An Empirical Test. Organization Science, 6 (1), 76-92 